\title{
En meget kort introduktion til koranforskning
}

\begin{abstract}
Af Thomas Hoffmann
Koranforskningen er en af islamforskningens klassiske discipliner. Så godt som alle verdens førende islamologer og arabister har på et eller andet tidspunkt i deres karriere gransket dette kanoniske helligskrift. Det er forfatterens sigte at give læseren et introducerende overblik over koranforskningens milepæle og repræsentative arbejder.
\end{abstract}

Koranen (arabisk al-Qur'ân) er som bekendt muslimernes primære helligskrift og regnes i traditionel muslimsk forstand for den monoteistiske gud Allâhs åbenbaringer (tanzilât) til profeten (nabiy) og budbringeren (rasul) Muhammad, som herefter reciterede (Qur'ân er egentlig et verbalnomen afledt af verbet 'at recitere, foredrage'; qara'a) disse åbenbaringer for sine samtidige i perioden 610-632, først og fremmest i byerne Mekka og Medina i regionen Hidjâz på den arabiske halvø. I årene efter Muhammads død blev det i stigende omfang klart for lederne (kalifferne, al-khulafa) af den nye muslimske menighed (umma), at det var nødvendigt at samle og nedskrive de mundtlige overleveringer samt de spredte stykker af nedskrevne åbenbaringer. Den 'boglige' udgave (mushaf) af Koranen, som endeligt blev færdigredigeret under kaliffen 'Uthmân, kaldes for al-mushaf al'uthmânî og fungerer den dag $\mathrm{i}$ dag som den grundlæggende textus receptus for muslimer.

Ser man bort fra de teologisk-metafysiske præmisser og implikationer anerkender den moderne koranforskning i store træk en sandsynlig historicitet ved ovenstående model, men afviger i mange detaljer og præmisser fra den traditionelle muslimske model. Af mangel på samtidige ikke-islamiske historiske kilder og på baggrund af en berettiget tvivl om troværdigheden ved det ekstra-koraniske hadîth-materiale (særligt traderede minifortællinger eller udsagn af eller om Muhammad og hans nærmeste fæller), har et lille kontingent af mere eller mindre prominente forskere valgt at forkaste den basalt tillidsfulde model og i stedet præsentere en række alternative modeller, hvoraf nogle i deres radikalitet kunne kaldes revisionistiske (fx Crone \& Cook 1977; Wansbrough 1978, 2004; Luxenberg 2000). 
Parallelt med den radikale historiske skepticisme og den mere tillidsfulde approach trives en mere hermeneutisk og litteraturvidenskabelig forskning, hvor receptionshistorie, tekstanalyse og fortolkning udgør de videnskabelige fikspunkter. Hvor de forskere, som er interesseret i Koranens historiske genese, i princippet stræber efter én version af historien, er receptionshistorikerne og teksthermeneutikerne generelt mere orienteret mod en flerhed af modeller. Ud fra den idé at Koranen skal forstås som en fortløbende dialektisk begivenhed (fremfor et stykke stillestående historisk levn), der har og har haft vidt forskellige Sitz im Leben, arbejder enkelte af disse forskere tillige på at fremlæse hidtil undertrykte eller ubemærkede aspekter af Koranen. Eksempler herpå kan være feministiske læsninger af såvel muslimsk som ikke-muslimsk karakter (fx Wadud 1999; Stowasser 1994).

I nærværende oversigt vil de (fleste af de) mest banebrydende, indflydelsesrige og repræsentative arbejder vedrørende Koranens oprindelse og dens form og indhold blive præsenteret. Herudover vil jeg medtage en række nyere introduktioner og mindre monografier, som er gode til det hurtige og opdaterende overblik. Hovedvægten af materialet vil være engelsksproget. Det siger sig selv, at en stor blok primærlitteratur foreligger på arabisk, men for en introducerende artikel vil dette aspekt blive for omfattende. Endelig vil bud på nyere forskningstendenser blive opridset.

I forhold til bibelforskningens ekstremt differentierede subdiscipliner og skoledannelser står dagens koranforskning både i den heldige og uheldige position, at den stadig er til at overskue for den enkelte. Vælger man imidlertid at hente yderligere teoretisk og metodisk inspiration i bibelforskningen, lingvistikken og litteraturvidenskaben står man i princippet overfor et næsten lige så uoverskueligt og vildtvoksende felt. Derfor vil nærværende oversigt også tage sig den frihed at hugge ikke så få hæle og tæer, da en fyldestgørende Stand der Forschung alligevel fordrer en decideret monografi. En sådan mangler faktisk indtil videre, men følgende artikler er yderst nyttige supplementer til dette forskningshistoriske desideratum: Daniel Madigans "Reflections on Some Current Directions in Qur'ânic Studies" (1995) og Angelika Neuwirths stramt disponerede og 
yderst differentierede "Koran" fra Grundriss der Arabischen Philologie (1987). Den yngste artikel, Mohammed Arkouns "Contemporary Critical Practices and the Qur'ân" (2001), er trods sin plads som encyklopædi-artikel skæmmet af forfatterens næsten frankofile indsyn og polemiske opgør.

\section{Sine qua non - de absolut uomgangelige}

For koranforskeren er tre kilder sine qua non. For det første islamforskningens moderskib, The Encyclopaedia of Islam. For det andet islamforskningens grundlæggende navigationssystem Index Islamicus. For det tredje den nye encyklopædiske krone på værket The Encyclopaedia of the Qur'ân (2001-2006), herefter forkortet til EQ. En fjerde kilde fortjener at blive udnævnt som enhver koranstuderendes vademecum, nemlig Bernhard Maiers fremragende og bibliografi-pakkede Koran-Lexikon (2001).

\section{Introduktioner og generelle indføringer}

En nyklassiker er Rudi Parets koranoversættelse Der Koran med supplementbindet Kommentar und Konkordanz (1979). Kommentarbindets henvisninger til parallelsteder, annotationer til og bud på de enkelte koranvers gør den til en nyttig følgesvend til de fleste korananalyser. Den engelsksprogede pendant til Paret er dels Richard Bells Bell's Introduction to the Qur'ân (1970) dels Bells The Qur'ân. Translated, with a critical rearrangement of the Surahs (1937) til hvilken der også er knyttet et omfangsrigt og detaljeret (men ufuldendt) kommentarværk, A Commentary on the Qur'ân.

For det meget hurtige overblik skal to nylige fine introduktioner nævnes: dels Hartmut Bobzins Der Koran. Eine Einführung (1999), dels Michael Cooks Koranen. En meget kort introduktion (2003, org. 2000). For den mindre fortravlede studerende står Hans Zirkers Der Koran. Zugänge und Lesarten (1999) som en originalt disponeret introduktion, der er meget opmærksom på Koranens semiotiske originalitet vis-à-vis Bibelen. Samme skudsmål gælder Neal Robinsons Discovering the Qur'ân. A Contemporary Approach to a Veiled Text (2003), men denne bog udmærker sig yderligere ved sit stringente og olympiske overblik over Koranens sprogligt formelle aspekter. En anden yderst systematisk og hurtig oversigt finder man i Alford Welchs "Al- 
Kuran" fra The Encyclopaedia of Islam. For antikvariatgængerens vedkommende kan Frants Buhls Muhammeds Forkyndelse efter Qurânen (1924; bemærk den mere korrekte transskription) ofte erhverves til en fordelagtig pris.

\section{Form og indhold}

At tale om form og indhold som to adskilte størrelser anskues i moderne litteraturvidenskab og tekstanalyse som forfejlet. Nærmere skal form og indhold forstås som komplementære dimensioner, hvor indholdet (semantik, tematik, handlingssekvenser m.m.) griber ind i formen og vice versa. Eksempelvis: Når Gud i sura 112 præsenteres som ahad (én) og dernæst lader én(heden) rime på samad (massivitet; ubrydelighed), kan man i realiteten ikke længere skelne mellem rimets formelle struktur, dets evne til syntese mellem arbitrære ord, og den basale koraniske semantik om Guds absolutte enhed (tawhîd). Derfor skal opdelingen i form og indhold først og fremmest betragtes som en heuristisk metode, der må opløses i de mere tekstnære og specialiserede læsninger. For en buket af små eksemplariske nærlæsninger, hvor form og indhold læses som to sider af samme sag, se Michael Sells' Approaching the Qur'ân. The Early Revelations (1999).

\section{Koranens sproglige form}

Sprog

"Sandelig, Vi har åbenbaret den som en arabisk Koran [qur'ânan 'arabiyyan]." Med dette citat fra sura 12:2 skulle det synes indlysende, at Koranens sprog er arabisk, men der er ikke desto mindre flere forskellige standpunkter vedrørende koranisk arabisk. Forskningsmæssig konsensus går på, at Koranens arabiske er holdt i et særlig supraregionalt Kunstsprache kaldet 'arabiya (markeret ved visse grammatiske og prosodiske forhold), som sædvanligvis kun blev benyttet ved oratorier og poesiforedrag. Dette 'arabiya fungerede $\mathrm{i}$ en vis forstand som den arabiske halvøs kulturelle lingua franca. Et sådan diglossi-forhold ligner situationen for moderne arabisk, som også er opdelt i dialekter og 'gadesprog' (al-'amiyâ) og det man kunne kalde rigsarabisk (al-fusha). Forholdet mellem Koranens sprog og dette poetiske koiné er grundigt belyst i Michael Zwettlers The Oral Tradition of Classical Arabic Poetry (1978). 
Koranens sprog er imidlertid ikke et 'rent' arabisk, men et arabisk med adskillige fremmede ord. Ikke mindst er mange religiøse termer fra hebraisk, aramæisk, syrisk og ætiopisk inkorporeret. Arthur Jefferys The Foreign Vocabulary (1938) er stadig standardværket, men dets svage teori og metodologi afhjælpes delvis af Martin Zammits A Comparative Lexical Study of Qur'ânic Arabic (2002). I dette værk får man et grundigt overblik over Koranens semitisk-sproglige netværk, hvor ikke kun hebræisk men også uddøde og mindre kendte sprog som akkadisk, ugaritisk, ge'ez og syrisk behandles.

Indenfor de sidste par år har især én revisionistisk hypotese tiltrukket sig opmærksomhed (sågar med en forside på New York Times). Det er pseudonymet Christoph Luxenbergs Die Syro-aramäische Lesart des Korans (2000), hvis overraskende konklusion er, at Koranen oprindeligt er skrevet på syrisk-aramæisk og først senere oversat til arabisk. Dette skulle bl.a. kunne forklare såkaldte uforståelige passager i Koranen. Claude Gilliot og Pierre Larcher er positivt indstillede overfor denne hypotese (samt Günther Lülings idé om, at Koranen rummer et oprindeligt lag af nestoriansk-kristne tekster). De allerfleste semitiske filologer og koranforskere har dog fuldstændig afvist disse hypoteser som værende filologisk fejlagtige og spekulative indtil det konspiratoriske. Nærværende forfatter ser en slags filologiens Da Vinci Mysteriet i Luxenbergs grundlæggende tese og analyser, men er dog enig $\mathrm{i}$ at Koranen rummer forskellige syriske elementer og forbindelser. For en hurtig gennemgang af de forskellige positioner (med en positiv evaluering af Luxenberg!), se Gilliot og Larchers "Language and Style of the Qur'ân" i $E Q$.

For den studerende, som ønsker en mere praktisk og brugsorienteret tilgang til Koranens sprog, kan W.M. Thackstons An Introduction to Koranic and Classical Arabic (1994) og Alan Jones' Arabic Through the Qur'ân (2005) med fordel konsulteres.

\section{Leksikon}

De hurtigste nøgler til Koranens leksikon (dvs. dens ord) er dels John Penrices noget forældede A Dictionary and Glossary of the Kor'ân (1873), dels Arne Ambros' og Stephan Procházkas A Concise Dictionary of Koranic Arabic (2004). Efter sigende skulle 
koranforskeren og oversætteren M.A.S. Abdel Haleem også være ved at barsle med en koranordbog. Ved siden af Jefferys The Foreign Vocabulary (1938) er Zammits $A$ Comparative Lexical Study of Qur'ânic Arabic (2002) som nævnt en vigtig nøgle til Koranens pan-semitiske ordskat. Endvidere skal Josef Horovitzs Koranische Untersuchungen (1926) nævnes, da den rummer en systematisk gennemgang af Koranens egennavne (fx Iblîs, Ibrâhîm, 'Îsâ, Mariam, Manât). Koranens klassiske leksikalske hovedmysterium er de såkaldte mystiske bogstaver, ${ }^{1}$ dvs. ét til fem bogstaver, som ikke danner noget egentlig ord og som indleder 29 af Koranens 114 suraer. Adskillige koranforskere har kastet sig over denne 'bogstavelige' gåde. J.A. Bellamys tese om at disse udgør en slags forkortelse er for epitetet al-rahmân eller al-rahîm regnes generelt for den stærkeste. En oversigt over forskningspositioner findes i Keith Masseys "The Mysterious Letters," $E Q$.

\section{Grammatik}

I EQs artikel "Grammar and the Qur'ân" bemærker Rafael Talmon, at uanset at ethvert værk om klassisk-arabisk grammatik belyser Koranens grammatik, findes der endnu ikke et samlende værk, der udtømmende beskriver og analyserer Koranens grammatiske karakteristika og særegenheder. Det hidtil mest ambitiøse bud er Bahmani Nedjars firebindsværk Grammaire fonctionelle de l'arabe du Coran (1988). Et mindre antal monografier og artikler tager enkelte grammatiske elementer op til behandling (se Talmons bibliografi) og inddrager ofte stilistiske og fortolkningsmæssige aspekter, $\mathrm{fx}$ Arne Ambros" "Syntaktische und stilistiche Funktionen des Energikus im Koran" (1989). Grammatiske særtræk som eksempelvis intensiv, dualis, passiv og ordstilling har vist sig som mere end blot formelle grammatiske elementer. At koraneksegesen (tafsîr) var afgørende for udviklingen af den teoretiske, deskriptive og normative grammatik blandt de tidlige arabisk-talende muslimer er almindeligt accepteret. C.H.M. Versteeghs Arabic Grammar and Qur'ânic Exegesis in Early Islam (1993) er et bud på, hvordan denne udvikling fandt sted og konsoliderede sig.

\footnotetext{
${ }^{1}$ De forskellige arabiske betegnelser er egentlig mere præcise; fx 'åbnere af suraerne' (fawâtih al-suwar), 'suraernes allerførste' (awa 'il al-suwar) eller 'de adskilte bogstaver' (al-hurûf al-muqatta'a).
} 


\section{Stil og retorik}

Et genkommende tema i Koranen er Muhammads afvisning af at være digter og orakel. Denne afvisning har affødt spørgsmålet om, hvorfor Koranens sprogbrug ikke desto mindre fik Muhammads modstandere til at skyde skød ham digter-betegnelsen i skoene. Zwettler argumenterer i sin The Oral Tradition of Classical Arabic Poetry (1978) for, at Koranens stilistiske genistreg bestod i genremæssig transduktion, dvs. det forhold at en eller flere genrer og stillejer (in casu poesien) overføres til en anden kontekst (liturgiens) En anden undersøgelse, udført af Alan Jones (1993), arbejder også ud fra præmissen, at Koranens sprog afspejler præ-koranisk sprogbrug. Jones identificerer fire forskellige sproglige registre eller diskurser: 1) orakulær (kâhin) diskurs; 2) oratorisk (khatîb) diskurs; 3) historiefortæller (qâss) diskurs; 4) skriftligt dokument diskurs. Spor af disse genfindes i Koranen, men mestendels fremstår de i den nye syntese, som adskiller Koranens stil fra andres.

Inden for de sidste femten år har koranforskningen tildelt Koranens litterære træk en stadig større opmærksomhed. Ikke mindst G.R. Hawting \& A.K. Shareefs antologi Approaches to the Qur'ân (1993) samt Stefan Wilds ditto, The Qur'an as Text (1996), markerede en ny åbenhed i forskersamfundet overfor litterære, retoriske og semiotiske tilgange. Hvor Koranen i ældre forskning ofte blev kritiseret som værende rodet og stilistisk umoden og i klassisk eksegese overvejende blev læst og forvaltet ud fra etiskretlige kriterier, har en række nye læsninger med inspiration fra litteraturvidenskaberne lagt vægt på kompositorisk kohærens og hidtil upåagtede fortolkningsmæssige dimensioner. I forlængelse af disse nye tiltag har nærværende forfatter (Hoffmann 2005) plæderet for en poetologisk læsning af Koranen, da vitale komponenter af Koranens sprogbrug udviser træk af poetisk sprogbrug, hvilken lingvisten Roman Jakobson kaldte for den poetiske funktion. Den poetiske funktion nedtoner det kommunikative sprogs referentielle funktion og $\mathrm{i}$ stedet oparbejdes en slags sproglig selv-centrering og fortætning, hvori formelle mønstre som rekurrens ( $\mathrm{fx}$ rim, alliteration, parallelisme), mærk-værdiggørelse (ofte kaldet deviation eller defamiliarization) i forhold til et hypotetisk kommunikativt standardsprog ( $\mathrm{fx}$ specielle ord, syntaks, figurer og troper), semantisk ambiguitet (fx labil udsigelse, allusioner, gådefulde ord og vendinger), lyd- 
symbolik (fx onomatopoetika, ordspil), litterær selv-referentialitet og kvasi-musikalsk performance tiltager sig en prominent rolle. En vigtig poetologisk forløber er Navid Kermanis Gott ist Schön. Das Erleben des Korans (2000), som også fungerer som en art receptionshistorie over muslimernes religiøst-æstetiserende omgang med og forståelse af Koranen.

\section{Komposition, kronologi og kanonisering}

Koranens komposition i suraer og vers (sing. aya, plur. ayât), primært dens kronologi, sekundært dens litterære kohærens og/eller mangel på samme, udgør i lighed med Koranens kanonisering et særdeles kompliceret og omtvistet problemfelt.

Koranen er opdelt i 114 suraer, der igen er grupperet efter et omtrentligt kvantitativt princip, hvor suraerne aftager i længde. Især de kortere suraer synes at være konciperede som enheder, mens nogle af de længere nærmere må anskues som en slags liturgiske læsestykker eller perikoper, der er blevet redigeret sammen på et andet tidspunkt end de enkelte vers’ åbenbaringssituation. Koranen nævner selv, at et vers kan ophæves eller modificeres af et senere åbenbaret vers (det kaldes også abrogration; arab. naskh). Traditionel muslimsk eksegese opererer endvidere med de såkaldte åbenbaringssituationer (asbâb an-nuzĥl), hvorunder koranversene tilsyneladende skulle være blevet åbenbaret. Koranmanuskripter viser endvidere, at man tidligt skelnede mellem suraer, der blev åbenbaret før og efter hidjrâ (udvandringen fra Mekka i 622), dvs. mellem såkaldt mekkanske og medinensiske vers. I den ægyptiske standardudgave fra 1923 angav man i suraoverskiften endvidere, hvilken sura der mentes at komme kronologisk før den nærværende sura. Endelig blev det også anført, hvis der tænktes at være medinensiske indskud i de mekkanske suraer.

Den dag i dag står Theodor Nöldekes Geschichte des Qoorans (1909-1938) som den moderne koranforsknings pionerværk. Nöldekes opdeling af korankronologien (på baggrund af stilistiske analyser) i tre mekkanske perioder efterfulgt af en fjerde medinensisk er ikke indiskutabel, men hypotesen står fortfarende stærkt. Den vestlige koranforskning anerkender generelt også Koranens kronologiske 'tilstand' og det 
banebrydende skel mellem mekkanske og medinensiske suraer, men er mere kritisk indstillet overfor værdien af de ekstra-koraniske kilder (fx vedr. åbenbaringsituationer). I et forsøg på at etablere mere uafhængige parametre for kronologisering har formelle og indholdsmæssige kendetegn vist sig nyttige. Med udgangspunkt i Gustav Weils teori om yderligere periodisering forfinede Nöldeke analysen og kom frem til tre mekkanske perioder fulgt af en medinensisk. Nöldekes periodisering er blevet suppleret og udfordret af alternative hypoteser (Hirschfeld 1902; Muir 1903; Bell 1937; Wansbrough 2004) og på baggrund heraf må Nöldekes skematik stadig gentænkes.

Som fremgået af de forrige afsnit er Koranens nuværende kanoniske status resultat af en længere proces. Således har William Graham i Divine Word and Prophetic Word in Early Islam (1977) vist, at man i tidlig islam ikke skelnede skarpt mellem Profetens udsagn ( hadîth) og guddommelige udsagn (såvel Koranens som de såkaldte hellige hadîth, hadîth $q u d s \hat{\imath})$, hvor Gud forstås som den oprindelige taler. Koranen som den forefindes i dag er således resultatet af et længere work-in-progress.

En radikal alternativ tese er blevet fremført af John Wansbrough. Iflg. Wansbrough må Koranen læses som en samling af uafhænge profetiske logia, der florerede i det mesopotamiske område (og altså ikke det klassiske hijâz-område med Mekka og Medina) i de første to århundreder efter det islamiske imperiums udbredelse. En kanonisk Koran kan efter Wansbroughs mening ikke spores før omkring det tredje århundrede A.H. (anno Hegirae, 'hijra-året,' dvs. efter 622), og denne må så nærmere betragtes som et stykke konstrueret anakronistisk frelseshistorie fremfor et brugbart dokument om profeten Muhammad. Wansbrough underbygger sit argument med en indsigt fra hadîthvidenskaben, hvor tidligere forskere som Ignaz Goldziher (1889-90) og Joseph Schacht (1950), kunne bevise, at mange hadîth var af dubiøs historisk værdi. Disse hadîth var konstruerede ud fra en senere tids strategisk-dogmatiske polemikker og på anakronistisk vis (vha. falske overleveringskæder) skudt bagud til Muhammads samtid.

Selvom de færreste forskere anerkender den mesopotamiske tese om vidt forskellige logia samt den ekstremt udvidede tidsramme, har Wansbroughs arbejde været 
udslagsgivende for en ny attitude til det koraniske materiale, hvor Muhammads unikke 'forfatterskab' nærmere betragtes som et samarbejde med og efterarbejde af flere instanser (menighed, andre religiøse samfund, skrivere, redaktører m.v.). Et slags kompromis mellem Wansbrough og konsorter (Crone \& Cook 1977; Hawting 1999 m.fl.) og mainstream-koranforskning finder man hos Harald Motzki, der mener at kunne bevise, at de muslimske kilder er betragteligt nærmere den klassiske islamiske datering, end den vestlige forskning hidtil har antaget (Motzki 2001).

\section{Mundtlighed og skriftlighed}

Koranen er et helligskrift udsprunget af et altovervejende mundtligt miljø. Selvom Koranen om noget er en hellig tekst i en såkaldt bogreligion, er dens sprog gennemsyret af den mundtlige 'litteraturs' typiske kendetegn. Ligeledes forvaltes Koranen rituelt på en sådan måde, at dens mundtlige/lydmæssige dimension tiltager sig en betydelig rolle.

Den store brede komparative monografi om mundtlighed og helligtekster er forfattet af William Graham. Hans Beyond the Written Word (1987) behandler først og fremmest fænomenologiske og teologiske aspekter af jødedommens, kristendommens, islams, og hinduismens mere eller mindre mundtlige helligtekster. Grahams sigte er at åbne for de mundtlige og klanglige dimensioner, som de videnskabelige tekstlæsningsfag har en tendens til at forbigå. En langt mere teknisk og specialiseret tilgang til mundtlighed i den arabiske tradition yder Michael Zwettlers The Oral Tradition of Classical Arabic Poetry (1978). Specielt Zwettlers diskussion af Koranens appropriation og transformation af poesiens særlige diktion er vigtig. I forlængelse af det forskningfelt, som studerer formulariske mønstre i mundtlige og nedskrevne tekster, er Robinsons katalog over faste vendinger og topoi igen nyttig. Også Angelika Neuwirths Studien zur Komposition der mekkanischen Suren (1981), hvori forfatteren argumenterer for en bestemt formulariskliturgisk struktur bygget over rimmønstre og de såkaldte 'cola' (en slags mundtlighedens semantiske mindsteenhed), er særdeles oplysende.

Det nødvendige komplement til Koranens mundtlighed er naturligvis dens skriftlighed. Trods forskningens stærke betoning af Koranens oprindeligt mundtlige kontekst, er det 
indlysende, at den koraniske tekst som skrift har fået en enorm betydning; fx i form af kalligrafiske pragtværker, arkitektonisk dekoration og - siden bogtrykningens intro i Mellemøsten - masseproducerede Koraner. Sidste skud på stammen er internetkoraner.

Det præ-islamiske Arabien bliver i populære fremstillinger ofte fejlagtigt beskrevet som skriftløst. Dels var der større befolkningsgrupper af jøder og kristne på den arabiske halvø, som ikke var analfabeter, dels er der enkelte spor fra den præ-islamiske (og ellers strengt mundtlige) poesi, der antyder kendskab til skrift. Ligeledes omtaler Koranen selv nedskrivning (2:282-3; 24:33) og skriftlige fænomener som bøger, pen, blade, blæk m.m. adskillige gange. Yderligere indikatorer og argumenter for præ- og tidlig islamisk skriftlighed finder man i Alan Jones' EQ-artikel "Writing and Writing in Arabia" (2003) og Gregor Schoelers "Schreiben und Veröffentlichen. Zu Verwendung und Funktion der Schrift in den ersten Islamischen Jahrhunderten" (1992). Også Muhammadforskningen har opgivet den traditionelle islamiske forestilling om, at Muhammad var analfabet. En hypotese om diktatets mundtlig/skriftlige status og funktion i forhold til Muhammads påståede analfabetisme er fremsat af forfatteren (Hoffmann 2005).

\section{Indhold}

\section{Semantik og semantiske mønstre}

Et af de mest centrale spørgsmål for koranstudier er naturligvis spørgsmålet om dens mening, dens semantik. Hvad betyder de enkelte ord, og hvad betyder de i sammenhængen? Dette spørgsmål vanskeliggøres især af, at Koranen er det altovervejende fons et origo for den nedskrevne arabiske litteratur; dvs. at den præislamiske poesi først er blevet nedskrevet i de islamiske århundrede. I lyset af Wansbrough og andres studier er autenticiteten heraf tillige blevet bragt i tvivl. Og når man ikke har en anden litteratur og dennes specifikke ordbrug at sammenligne med, bliver det med ét meget vanskeligt at bestemme den specifikke betydning af Koranens enkelte ord.

To banebrydende arbejder er blevet præsenteret af japaneren Toshihiko Izutsu (1964, 1966). Izutsu er en af de få videnskabsfolk, hvis arbejde generelt prises lige højt af såvel 
muslimske som ikke-muslimske forskere. Izutsu skrider til værks med grundlæggende synkroniske metoder, hvor en række nøgleord dels forsøges afkodet mht. en grundbetydning, dels mht. en relationel betydning. Det er særligt den relationelle betydning, som er afgørende for ordets koraniske farvning. I en række diagrammer centreret om ét såkaldt fokusord og en række omkransende nøgleord skaber Izutsu klarhed over den koranisk Weltanshauungs leksikalske systematik og viser, hvorledes Koranen i sig selv mønstrer en sammenhængende etisk-religiøs begrebsverden, som generelt er baseret på en skelnen mellem negative og positive værdier (ofte kontrasteret systematisk). Nogle år tidligere var en strengt strukturalistisk analyse blevet forsøgt af Michel Allard et al., men resultaterne er desværre vanskelige at afkode (1963). En forholdsvis ny blanding af strukturalistisk og litteraturfænomenologisk analyse finder man i Heidi Toelles Le Coran Revisité. Le Feu, l'Eau, l'Air et la Terre (1999).

Selvsagt beskæftiger de fleste koranstudier sig med semantiske aspekter, men tidligere nævnte Zirker giver en original behandling af makro-semantikken med kapitler opdelt efter 'tid og tider', 'rum og steder', 'aktører,' 'værdier og forpligtelser' m.m. Også Fazlur Rahmans Major Themes of the Qur'ân (1980) fungerer som en skarpsindig og muslimsk funderet introduktion. For Koranens forskellige mikro-, medio- og makro-semantikker yder $E Q$ (med sine opdaterede bibliografier) den bedste tilgang.

\section{Narrativer}

Når man taler om koranisk narrativitet skal man ikke forveksle en sådan med den type narrativitet, der præger epikken, romanen og novellen. Nærmere er der tale om narrative passager eller episoder, hvoraf nogle givetvis er konciperet således, at tilhøreren (og senere læseren) formodes at have kendt baggrunden for fortællingen på forhånd. Hovedværket er Heinrich Speyers Die biblischen Erzählungen im Qoran (1931). Værkets styrke er dets forbindelseslinjer mellem bibelsk (jødisk og kristen) litteratur og Koranens fortællinger. Dets svaghed er ikke overraskende de manglende selvstændige læsninger af Koranens narrativer. Et nyt supplement til Speyer er Roberto Tottolis Biblical Prophets in the Qur'ân and Muslim Literature (2002). 
To narrative størrelser er særligt blevet undersøgt: 1) sura 12, dvs. Josef-suraen der ligner den bibelske Josef-fortælling (og dermed også er blevet eksemplet par excellence mht. temaet om bibelsk derivat eller koranisk originalitet) og 2) de såkaldte straffelegender som på en ret skematisk litterær vis omhandler Guds tidligere profeter og advarere og deres erfaringer med genstridige stammer og nationer. Sidstnævnte begreb blev dannet af Josef Horovitz i sin Koranische Untersuchungen (1926), hvor han tillige undersøger andre fortællende afsnit i Koran. Et nyt studie af straffelegenderne er David Marshalls God, Muhammad and the Unbelievers (1999). Blandt de forskellige Josef-studier kan nævnes Heinrich Speyer (1931), Marilyn Waldman (1986), A.J. Hämeen-Anttila (1991).

\section{Ritualitet}

Hvis man ved, at den etymologiske rod i ordet Koran betyder 'fremsigelse' og tillige kender til Koranens stilling i muslimsk fromhedsliv kan det ikke overraske, at det rituelle indtager en vigtig rolle. Her kan man grundlæggende skelne mellem to slags studier: 1) studier der undersøger Koranens opkomst og rationale i et ritualiseret miljø og 2) studier, der undersøger Koranens synkrone ritualitet og ritualiserede brug i forskellige samtidige kontekster.

Et vigtigt eksempel fra pkt. 1 er Angelika Neuwirths Studien zur Komposition der mekkanischen Suren (1981) og artiklen "Von Rezitationstext über die Liturgie zum Kanon" (1996), der samler op på det liturgisk-rituelle argument og sætter det i forbindelse med Koranens interne 'kanoniseringskontrakt.' Et andet eksempel er Gerald Hawtings The Idea of Idolatry and the Emergence of Islam: From Polemic to History (1999). Oleg Grabars "Art and Architecture and the Qur'an," EQ, yder en fin introduktion til Koranens sammenhæng med en ritualiseret materiel kultur (fx moskeer).

Fra pkt. 2 må to studier i Koranens recitationskunst og uddannelsessystem nævnes: dels Kristina Nelsons The Art of Reciting the Qur'ân (2001) og Anne Gades Perfection Makes Practice [sic!]. Learning, Emotion, and the Recited Qur'ân in Indonesia (2004). Nærværende forfatter har i artiklen "Ritual Poeticity in the Qur'ân” (Hoffmann 2004) 
plæderet for en særlig poetisk-ritualistisk sprogbrug i Koranen. For en introduktion til feltet, se Josef W. Meris "Ritual and the Qur'ân," $E Q$.

\section{Eksegese}

Koranen 'i sig selv' er et yderst problematisk begreb, og receptionsforskningen og eksegesen er det bedste eksempel på, at Koranens budskab afhænger af øjnene der ser, hvad enten det er betinget af den enkelte ekseget eller bredere socio-kulturelle strømninger. Koranen er da også blevet kaldt en tekst uden en kontekst og som sådan stærkt afhængig af kontekstualiserende kommentarer. Dette forhold afspejles på metatekstuel vis i Koranen selv, da flere vers indledes med vendingen "de spørger [dig, dvs. Muhammad]" for herefter at blive 'besvaret' af Profeten. Svar, der ikke talte som åbenbaringer, blev til de såkaldte hadith (egt. 'en udmelding, nyhed'). Efter Muhammads død voksede de til et omfangsrigt korpus med tusindvis af hadîth, hvoraf mange i moderne hadîth-videnskab dog regnes for at være konstruerede med sigte på at afklare samtidige teologiske stridspunkter, som for legitimerings skyld er blevet tilskrevet Muhammad. Dette forhold var de muslimske eksegeter også bevidste om, og følgelig opererede de med en slags troværdighedsskala. En meget brugt introduktion til hadith er John Burtons An Introduction to the Hadith (1994).

Ved siden af hadîth finder man de eksegetiske værker, der kan grupperes alt efter om vægten er på det filologiske, retorisk-stilistiske, opbyggelige og oplysende (fx navne på unavngivne figurer i Koranen), juridisk eller mystisk-allegorisk (undertiden kaldet ta'wîl). Et tidligt hovedværk er Ignaz Goldzihers Die Richtungen der islamischen Koranauslegung (1920), i hvilken han gennemgår eksegesens udvikling fra sin spæde start til moderne tid. I nyeste tid er det absolut mest omfangsrige (seks tykke bind) og grundige værk om tidlig muslimsk teologi og eksegese Josef van Ess' Theologie und Gesellschaft im 2. und 3. Jahrhundert Hidschra (1991-95). Muslimske forskere har i de senere år præsenteret en forskning, som også giver bud på, hvordan eksegese kan fornys og genforhandles. Hermed indgår de også i et apologetisk opgør med henholdsvis en traditionalistisk og islamistisk eksegese. Repræsentanter for denne strømning kunne være 
Muhammad Arkoun og hans Rethinking Islam: common Questions, uncommon Answers (1994) og Abdullah Saeeds Interpreting the Qur'ân (2006).

\section{Muhammad}

Uanset Muhammads prekære situation i moderne koranforskning er Muhammad stadig et vigtigt emne i forskningen. En fremragende introduktion er for nyligt leveret af Hartmut Bobzin, hvis Mohammed (2000) rummer de vigtigste fakta og stridspørgsmål i Muhammad-forskningen. Ligesom Bobzin har Michael Cook også skrevet en kortfattet Muhammad-biografi (1985). Et andet nyt Muhammad-studie er skrevet af Clinton Bennett, hvis In Search of Muhammad (1998) er en slags receptionshistorie af Muhammdforskningen, der gennemgår et stort bredt udvalg af muslimske, kristne og ikke-kristne Muhammad-positioner. To moderne hovedværker er dels Maxime Rodinsons Muhammad (1971) og W. Montgomery Watts Muhammad at Mecca (1953) og Muhammad at Medina (1966). En antologi med de nyeste bud fra Muhammadforskningen finder man i Harald Motzkis The Biography of Muhammad: The Issue of the Sources (2000).

Det danske hovedværk indenfor Muhammad-forskningen er ubetvivleligt den danske teolog Frants Buhls Muhammeds Liv (1903, oversat til tysk i 1930). Buhls biografi havde på daværende tidspunkt den mest omfangsrige behandling af de islamiske kilder samtidig med, at den tegner et særdeles levende billede af Muhammads arabiske miljø. Buhl læser Koranen som et dokument til Muhammad liv og lære. I en stærkt historisk-kritiske ånd er Buhl fokuseret på at udpege modsigelser og jødisk-kristne indflydelser i teksten, herunder at læse Muhammads teologi som udtryk for et projekt, der efterhånden blev korrumperet af politisk-strategiske motiver.

Klassisk Muhammad-forskning stræbte i høj grad efter at præsentere en Muhammadbiografi, der kunne leve op til historikeren Rankes (1795-1886) ideal om at forstå historien wie es eigentlig gewesen ist. Dette positivistiske ideal er efterhånden blevet kraftig eroderet; et fornemt eksempel er Uri Rubins The Eye of the Beholder: The life of Muhammad as viewed by the early Muslims. A Textual Analysis (1995). 


\section{Komparation}

Koranen er sprogligt, intertekstuelt og tematisk i familie med en lang række religiøse skrifter. Dette anerkendes sågar i Koranen selv, der ofte omtaler bibelske skrifter som Torahen og evangelierne. I lyset af det forhold er det ikke overraskende, at en lang række koranstudier har været stærkt optaget af komparative analyser. Flere af de tidlige studier var ofte særligt optaget af at vise, at Koranen 'bare' var et derivat af tidligere religiøse skrifter (ofte betinget af forskerens religiøse baggrund der som regel var enten jødisk eller kristen), men trods denne lidt naive og positivistiske tilgang ydede studierne vigtige bidrag til belysningen af dét religiøse miljø, som Koranen havde baggrund i.

Et tidligt og banebrydende værk var Abraham Geigers Was hat Muhammed aus dem Judenthum aufgenommen (1833), i hvilken det (med henvisninger til rabbinsk og bibelsk litteratur) blev argumenteret, at koraniske forestillinger, ord og foreskrifter trak tunge veksler på jødisk materiale. Med dette værk blev grunden lagt for en tilgang, hvor det jødiske materiale mere eller mindre eksplicit blev antaget som dén originale målestok, ud fra hvilken Koranens eventuelle afvigelser skulle måles (fx Hirschfeld 1902). Ved siden af den 'jødiske tilgang' voksede en kristen ditto sig stærk med navne som fx Muir (1903), Nöldeke (1909ff) og Andræ (1918). De kristne forskere kunne for det første kommentere de passager i Koranen, som omhandler Jesus, Maria, Helligånden, evangelierne, kristne m.m., og de kunne i dem finde adskillige intertekstuelle linjer til kristen apokalyptisk og tidlig apologetisk litteratur. En særlig interesse har naturligvis samlet sig omkring Jesusfigurens rolle, selvom monografiernes antal egentlig er forbavsende lavt. Religionshistorikeren Edward G. Parrinders Jesus in the Qur'ân er anbefalelsesværdig (1955). En slags kompromis mellem disse to positioner finder man i Speyers Die biblischen Erzählungen im Qoran (1930). Fra dansk side finder vi bl.a. Jes P. Asmussens lille introduktion Muhammad Jesus Abraham. Kristendom og Jødedom i Koranen (1982).

Men Koranen står jo ikke kun i forhold til en bibelsk litteratur og bibelsk miljø, men udsprang naturligvis også af en genuin arabisk kultur. Her er M.M. Bravmanns The Spiritual Background of early Islam (1972) et uomgængeligt værk, der argumenterer for 
islams videreudvikling af præ-islamiske begreber og kulturelle praktikker. Et nyere introducerende værk, der ser islam og Koranens opkomst på en bredere semitisk baggrund er Robert G. Hoylands Arabia and the Arabs: from the Bronze Age to the Coming of Islam (2001).

Sjældnere fugle er værker, der går ud over det semitiske og bibelske miljø. Her bør dels nævnes Ary Crollius’ Thus They Were Hearing (1974), hvor Koranens vægtlægning på mundtlighed og oralitet sammenlignes med de indiske Vedaers ditto, dels Gottthart Strohmaiers Hellas im Islam (2003) om græske og hellenistiske indflydelser. Inden for de senere år synes bibelforskere på ny at være blevet interesseret i Koranen som en vigtig og original faktor i et bredere monoteistisk miljø. John Reeves antologi Bible and Qur'an. Essays in Scriptural Intertextuality (2004) vidner om dette.

\section{Koranoversæattelser og konkordanser}

Det er blevet sagt om oversættelser, at de er ligesom ægtefæller; hvis de er smukke, er de utro, og hvis de er tro, er de grimme. Det passer i slående grad til netop koranoversættelser, og det skyldes ikke mindst det arabiske sprogs grammatiskmorfologiske natur, som ofte kræver, at den europæiske oversætter bliver nødt til tilføje en lang række oplysende ord. Endvidere er over $80 \%$ af Koranen på rim og det er selvsagt vanskeligt at få til at stemme overens i en præcis oversættelse.

Den måske grimmeste men også generelt mest anerkendte præcisionsoversættelse er Rudi Parets (med supplerende kommentar- og konkordansbind). Arthur J. Arberrys The Koran Interpreted betragtes af mange koranforskere som 'King James'-versionen. Dens lay-out er meget anderledes end en standardkorans og ligner mere en digtsamlings midtcentrerede tekst. Endvidere har den et rudimentært versnummeringssystem, der gør den vanskelig hurtigt at finde rundt i. Til gengæld kan man bruge Hanna Kassis' $A$ Concordance of the Qur'ân (1983), der refererer til Arberrys oversættelse. For den arabiskkyndige er M.F. Abd al-Bâqîs al-Mu'jam al-muhfaras li-alfaz al-qur'ân al-karîm en af de mest anvendte konkordanser. 
Der findes flere muslimske oversættelser. En forholdsvis ny, der ikke synes at indtage særstandpunkter eller censurerer i teksten, er M.A.S. Abdel Haleems The Qur'ân (2004). Mange engelsksprogede muslimer er glade for Yusuf Alis (1934) og den britiske konvertit Muhammad Marmaduke Pickthalls (1930) oversættelser. Alis udmærker sig ved at dele de længere suraer op i sektioner, hvilket kan hjælpe læseren til at bedre at forstå suraens opbygning. Pickthalls engelske er holdt i en noget gammeldags (edwardiansk) tone, og ligesom Ali indskyder han parenteser, når han mener, at Gud henvender sig direkte til Profeten eller til muslimerne. Endvidere oversætter de ofte ord på forskellige måder, hvilket kan vanskeliggøre indsigten i Koranens semantiske netværksstruktur. Arberry, Alis og Pickthalls oversættelser har alle den fordel, at de skelner mellem et singularis 'du' ('thou') og et flertal 'I' ('ye' eller 'you'), hvilket kan være særdeles vigtigt for forståelsen af passagers henvendelsesstruktur. Dette problem undgår man naturligvis på dansk og tysk.

For danske studerende står indtil videre kun én fuldbåren oversættelse, nemlig A.S. Madsens Koranen. Denne udmærker sig i de senere udgaver ved at have den arabiske tekst trykt ved siden af den danske. Til gengæld er den præget af meget teologisk noteapparat, som her og der vidner om oversætterens tilhørsforhold til Ahmadiyya-islam (en retning som sunni- og shi'a-islam opfatter som kættersk). Endvidere er der enkelte deciderede fejl og forglemmelser, fx 68:2, hvor 'det mystiske bogstav' 'n' (nûn) er glemt i oversættelsen. En meget rost svensk oversættelse er K.V. Zetterstéen (1917).

Andre danske oversættelsers største mangel er deres ufuldendte karakter. Således oversætter arabisterne Frants Buhl (1921) og F.O. Hvidberg-Hansen (2004) desværre kun udvalgte passager og den førstnævnte mangler et noteapparat. Hvidberg-Hansens forholdsvis uelegante men præcise Koranen $i$ udvalg er suppleret med et nøgternt og detaljeret noteapparat ligesom dens opdeling i tematiske blokke (fx Muhammads kaldelse; Koranen; Opstandelsen og dommedag; Drab og blodhævn; Vin- og spiseforbud) kan være en stor hjælp for den koranstuderende, men vil i reglen vise sig mangelfuld for mere dybtgående læsninger. År 2006 skulle efter alt at dømme byde på en fuldbyrdet oversættelse af den danske semitiske filolog, Ellen Wulff (2006). 


\section{Nyere forskningstendenser}

Hvor den litteraturvidenskabelige tilgang til Koranen har været tendensen i de sidste ti år, synes koranstudierne i øjeblikket at være grebet af mindre lokale turbulenser, som måske kan blive til deciderede strømninger. Følgende er således blot gætværk, men på såvel den nationale som internationale front vil jeg tro, at mere antropologisk-sociologisk orienterede undersøgelser af madrasaer, dvs. koranskoler, vil blive et fokusområde. Det skyldes naturligvis de islamistiske kim og strømninger, som man har bemærket i såvel diaspora- som hjemlandsmadrassaer.

Givetvis vil der også blive skabt fornyet opmærksomhed omkring bløde emner som dialog, forsoning og økumeni. Hvordan taler Bogens Folk med hinanden og kan der opstilles samtale-etiske tommelfingerregler? Muslimers, jøders og kristnes (men også hinduers, buddhisters og ateisters m.fl.) opfattelser af deres helligskrifters respektive autonomi og autoritet er qua de nye diaspora- og vesteuropæiske muslimer blevet langt mere akutte forskningsfænomener. Fagmæssigt vil det spænde fra sociologi, antropologi, islamologi, religionsvidenskab, teologi og jura.

Muligvis vil også den kognitive lingvistik og -religionsvidenskab blive en del af de nye koraniske forskningstrends. Indenfor religionsforskning har de kognitive videnskaber (dvs. studiet af menneskets mentale liv og dets forankring i naturlige processer) vist sig at kunne tilføre feltet helt nye og naturalistiske forklaringsmodeller, som et ellers højfilologisk- og hermeneutisk felt i lang tid har skyet. Her kan ikke mindst forskningsdisciplinen kognitiv lingvistik yde nye redskaber og teoretiske paradigmer i tilgangen til det koraniske tekstunivers.

\section{Koranoversæettelser}

Ali, Abdullah Yusuf, 2000 (org. 1934): The Holy Qur'an, Wordsworth Classic, Chatham. Arberry, A.J., 1964 (org. 1955): The Koran Interpreted, Oxford University Press, London.

Buhl, Frants, 1921: Quranen. Et Udvalg i kronologisk Rcekkefølge, København. Haleem, M.A.S.A., 2004: The Qur'ân, Oxford University Press, Oxford. 
Hvidberg-Hansen, F.O., 2004: Koranen. Udvalgte tekster, Høst, København.

Madsen, A.S., 1989: Koranen, Islam Internation Publications, Nusrat Djahan Moskéen.

Pickthall, Muhammad Marmaduke, 1930: The Meaning of the Glorious Qur'ân, Dorset Press, New York.

Wulff, Ellen, 2006 (forthcoming): Koranen, Forlaget Vandkunsten, Købehavn

Zetterstéen, K.V., 1917: Koranen, Wahlstöm \& Widstrand, Stockholm.

\section{Andre referencer}

Abd al-Bâqî, M.F., 1958: al-Mu'jam al-muhfaras li-alfaz al-qur'ân al-karîm, Kairo.

Adang, Camilla, 1996: Muslim Writers on Judaism and the Hebrew Bible: From Ibn Rabban to Ibn Hazm, Brill, Leiden.

Allard, Michel et al., 1963: Analyse conceptuelle du Coran sur cartes perforées, Mouton $\&$ Co., Paris.

Ambros, Arne A. \& Procházka, Stephan, 2004: A Concise Dictionary of Koranic Arabic. Reichert Verlag, Wiesbaden. , 1989: "Syntaktische und stilistiche Funktionen des Energikus im Koran", in: Wierner Zeitschrift für die Kunde des Morgenlandes, 79: 35-56.

Andræ, Tor J.E., 1918: Die Person Muhammads in Lehre und Glauben seiner Gemeinde, Archives d'études orientales 16, Stockholm.

Arkoun, Muhammad, 2001 "Contemporary Critical Practices and the Qur'ân", in: J. D. McAuliffe (ed.): Encyclopaedia of the Qur'ân, Brill, Leiden.

- 1994: Rethinking Islam: common Questions, uncommon Answers, Westview Press, Boulder.

Asmussen, Jes P., 1982: Muhammad Jesus Abraham. Kristendom og Jødedom i Koranen, C.E.G. Gad, København.

Bell, Richard, 1937: The Qur'an, Translated, with a Critical Re-Arrangement of the Surahs, T. \& T. Clark, Edinburgh. , 1991: A Commentary on the Qur'ân, University of Manchester Press, Manchester.

Bell, Richard \& W. Montgomery Watt, 1970: Bell's Introduction to the Qur'ân, Edinburgh University Press, Edinburgh.

Bellamy, J.A., 1973: "Old Abbreviations of the Basmalah",: Journal of the American Oriental Society 93: 267-85.

Bennett, Clinton, 1998: In Search of Muhammad. Cassell, London.

Bobzin, Hartmut, 1999: Der Koran. Ein Einführung, C.H. Beck, München

- 2000: Mohammed, C.H. Beck, München.

Boullata, Issa J., (ed.), 2000: Literary Structures of Religious Meaning in the Qur'an. Curzon, Richmond.

Bravmanns, M.M., 1972: The Spiritual Background of early Islam, Brill, Leiden.

Buhl, Frants, 1903: Muhammeds Liv, Gyldendal, København. , 1924: Muhammeds religiøse Forkyndelse efter Qurânen, J.H. Schultz Forlag, København.

Burton, John, 1994: An Introduction to the Hadîth, Edinburgh University Press, Edinburgh.

Busse, Heribert, 1998: Islam, Judaism and Christianity : Theological and Historical Affiliations, Markus Wiener Publishers, Princeton. 
Cook, Michael, 2000: The Koran, a Very Short Introduction, Oxford University Press, Oxford. , 1985: Muhammad, Oxford University Press, Oxford.

Crollius, Ary A.R., 1974: Thus They Were Hearing: the word in the experience of revelation in Qur'ân and Hindu Scripture, Documenta Missionalia, Rom.

Crone, Patricia \& Michael Cook, 1977: Hagarism. The Making of the Islamic World, Cambridge University Press, Cambridge.

van Ess, Josef, 1991-95: Theologie und Gesellschaft im 2. und 3. Jahrhundert Hidschra: eine Geschichte des religiösen Denkens im frühen Islam, Walter de Gruyter, Berlin.

Gade, Anne, 2004: Perfection Makes Practice. Learning, Emotion, and the Recited Qur'ân in Indonesia, University of Hawai'i Press, Hawai'i.

Geiger, Abraham, 1833: Was hat Muhammed auf dem Judenthum aufgenommen? Eine gekrönte Preisschrift, Bonn.

Gilliot, Claude \& Pierre Larcher, 2002: "Language and Style of the Qur'an", in: J. D. McAuliffe (ed.): Encyclopaedia of the Qur'ân, Brill, Leiden.

Gnilka, Joachim, 2004: Bibel und Koran. Was sie verbindet, was sie trennt, Herder, Freiburg im Breisgau.

Goldziher, Ignaz, 1960 (org. 1889-90): Muhammadanische Studien, Hildesheim, Georg Olms.

Grabar, Oleg, 2001: "Art and Architecture in the Qur'ân", in: J. D. McAuliffe (ed.):

Encyclopaedia of the Qur'ân, Brill, Leiden.

Graham, William A., 1987: Beyond the Written Word. Oral Aspects of Scripture in the History of Religion, Cambridge University Press, Cambridge.

_ 1977: Divine Word and Prophetic Word in Early Islam, Walter De Gruyter, The Hague.

Gätje, Helmut, 1996: The Qur'ân and Its Exegesis: Selected Texts with Classical and Modern Muslim Interpretations, Oneworld Publications, Oxford.

-1920: Die Richtungen der islamischen Koranauslegung, Leiden, Brill.

Hawting, Gerald R., 1999: The Idea of Idolatry and the Emergence of Islam: From Polemic to History, Cambridge University Press, Cambridge.

\& Abdul-Kader A. Shareef (eds.), 1993: Approaches to the Qur'ân, Routledge, London.

Hirschfeld, Hartwig, 1902: New Researches into the Composition and Exegesis of the Qoran, Royal Asiatic Society, London.

Hoffmann, Thomas, 2005: "Koranen som 'tekst'. Mellem mundtlighed og skriftlighed", in: Ole Davidsen og Kirsten Nielsen (eds.): Det Hellige og Litteraturen, Århus Universitets Forlag, Århus.

_ 2004: "Ritual Poeticity in the Qur'ân: Family Resemblances, Features, Functions and Appraisals", in: Journal of Qur'ânic Studies 6, no. 2: 35-55.

Horovitz, Josef, 1926: Koranische Untersuchungen, W. de Gruyter \& Co., Berlin.

Hoyland, Robert G., 2001: Arabia and the Arabs: from the Bronze Age to the Coming of Islam, Routledge, New York.

Hämeen-Anttila, A.J. 1991: "'We will tell you the best of stories': a study of Surah XII", in: Studia Orientalia 67: 7-32.

Izutsu, Toshihiko, 1966: Ethico-Religious Concepts in the Qur'ân, McGill University 
Press, Montreal.

, 1964: God and Man in the Koran; Semantics of the Koranic Weltanschauung,

Keio Institute of Cultural and Linguistics Studies, Tokyo.

Jeffery, Arthur, 1938: The Foreign Vocabulary of the Qur'ân, Oriental Institute, Baroda. Jones, Alan, 2005: Arabic Through the Qur'ân, The Islamic Texts Society, Cambridge.

- 2003: "Writing and Writing in Arabia" in: J. D. McAuliffe (ed.): Encyclopaedia of the Qur'ân, Brill, Leiden.

, 1993: "The Language of the Qur'ân", in: The Arabist. Budapest Studies in Arabic: 6-7.

Kadi, W. \& M. Mir, 2002: "Literature and the Qur'ân", in: J. D. McAuliffe (ed.): Encyclopaedia of the Qur'ân, Brill, Leiden.

Kassis, Hanna E., 1983: A Concordance of the Qur'ân. University of California Press, Berkeley.

Kermani, Navid, 2000: Gott ist Schön. Das Erleben des Korans, C.H. Beck, München.

Kugel, J.L., 1990: "A Mantic Manifesto: The Sûra of "the Poets", in: J.L. Kugel (ed.): Poetry and Prophecy. The Beginnings of a Literary Tradition, Cornell University Press, Ithaca.

Luxenberg, Christoph, 2000: Die Syro-Aramäische Lesart Des Koran. Ein Beitrag Zur Entschlüsselung Der Koransprache, Das Arabische Buch, Berlin.

Madigan, Daniel A., 2001: The Qur'ân's Self-Image. Writing and Authority in Islam's Scripture, Princeton University Press, Princeton. , 1995: "Reflections on Some Current Directions in Qur'ânic Studies," in: The Muslim World, vol. LXXXV, no. 3-4: 345-362.

Marshall, David, 1999: God, Muhammad and the Unbelievers, a Quranic study, Curzon Press.

Massey, Keith. "Mysterious Letters", in: J. D. McAuliffe (ed.): Encyclopaedia of the Qur'ân, Brill, Leiden.

McAuliffe, J.D., (ed.) 2001-2006: Encyclopaedia of the Qur'ân. Brill, Leiden.

- 1991: Qur'anic Christians. An Analysis of Classical and Modern Exegesis.

Cambridge, Cambridge University Press.

Meri, Josef, W., 2005: "Ritual and the Qur'ân", in: J. D. McAuliffe (ed.): Encyclopaedia of the Qur'ân, Brill, Leiden.

Mir, M., 2002: "Literature and Qur'ân", in: J. D. McAuliffe (ed.): Encyclopaedia of the Qur'ân, Brill, Leiden.

Motzki, Harald, 2001: "The Collection of the Qur'ân. A Reconsideration of Western Views in Light of Recent Methodological Developments," in: Der Islam 78: 1-34. , 2000: The Biography of Muhammad: The Issue of the Sources, Brill, Leiden.

Muir, William, 1903: The Corân : Its Composition and Teaching, and the Testimony It Bears to the Holy Scriptures, Society for Promoting Christian Knowledge, London.

Nedjar, Bahmani, 1988: Grammaire fonctionelle de l'arabe du Coran, RFA, Karlsruhe.

Nelson, Kristina, 2001 (org. 1985): The Art of Reciting the Qur'an, American University in Cairo Press, Cairo.

Neuwirth, Angelika, 2001: "Form and Structure of the Qur'ân", in: J. D. McAuliffe (ed.): Encyclopaedia of the Qur'ân, Brill, Leiden. 
1996 "Von Rezitationstext über die Liturgie zum Kanon", in Stefan Wild (ed.): The Qur'an as Text, Brill, Leiden, 1996.

- 1993: "Images and Metaphors in the Introductory Sections of the Makkan

Sûras", in: G.R. Hawting \& A.Abdul-Kader (eds.): .Approaches to the Qur'ân, Routledge, London.

, 1987: "Koran", in Helmut Gätje (ed.): Grundriss Der Arabischen Philologie.

Literaturwissenschaft, Dr. Ludwig Reichert Verlag, Wiesbaden.

, 1981: Studien Zur Komposition Der Mekkanischen Suren, De Gruyter, Berlin.

Nöldeke, Theodor, Friedrich Schwally, \& Gotthelf Bergsträsser, 1981 (org. 1909-38):

Geschichte Des Qorans, G. Olms, Hildesheim.

Paret, Rudi, 2001 (org. 1979): Der Koran \& Kommentar und Kondordanz, W.

Kohlhammer, Stuttgart.

Parrinder, Edward Geoffrey, 1955: Jesus in the Qur'an, Barnes and Noble, New York.

Penrice, John, 2004 (org. 1873): A Dictionary and Glossary of the Kor'ân, Dover

Publications, New York.

Rahman, Fazlur, 1980: Major Themes of the Qur'ân, Bibliotheca Islamica, Minneapolis.

Reeves, John C., 2004 (ed.): Bible and Qur'an. Essays in Scriptural Intertextuality, Brill, Leiden.

Rippin, Andrew, 2001: "Foreign Vocabulary", in: J. D. McAuliffe (ed.): Encyclopaedia of the Qur'ân, Brill, Leiden.

, 1983: "The Qur'an as Literature: Perils, Pitfalls and Prospects.", in: British Society of Middle Eastern Studies Bulletin 10, no. 1: 38-47.

Robinson, Neal, 2003: Discovering the Qur'an. A Contemporary Approach to a Veiled Text, Georgetown University Press, Washington, D.C.

Rodinson, Maxime, 1980 (org. 1971): Muhammad, Pantheon Books, New York.

Rubin, Uri, 1995: The Eye of the Beholder: The life of Muhammad as viewed by the early Muslims. A Textual Analysis, Darwin Press, Princeton.

Saeed, Abdullah, 2006: Interpreting the Qur'ân, Routledge, London.

Schacht, Joseph, 1950: The Origins of Islamic Jurisprudence, Clarendon Press, Oxford.

Schoeler, Gregor, 1992: "Schreiben Und Veröffentlichen. Zu Verwendung Und Funktion

Der Schrift in Den Ersten Islamischen Jahrhunderten", i: Der Islam 69, 1: 38-67.

Sells, Michael, 1999: Approaching the Qur'ân. The Early Revelations, White Cloud Press, Ashland.

Speyer, Heinrich, 1988 (org. 1931): Die biblischen Erzählungen im Qoran, G. Olms, Hildesheim.

Stowasser, Barbara Freyer, 1994: Women in the Qur'an, Traditions, and Interpretation. Oxford University Press, New York.

Strohmaier, Gotthart, 2003: Hellas im Islam: Interdisciplinäre Studien zur Ikonographie, Wissenschaft und Religionsgeschichte, Harrasowitz, Wiesbaden.

Talmon, R., 2002: "Grammar and the Qur'ân," , in: J. D. McAuliffe (ed.): Encyclopaedia of the Qur'ân, Brill, Leiden.

Thackston, Wheeler M., 1994: An Introduction to Koranic and Classical Arabic, Iranbooks

Thyen, Johann-Dietrich, 1989: Bibel und Koran. Böhlau, Köln.

Toelle, Heidi, 1999: Le Coran revisité. Le Feu, l'Eau, l'air et la Terre, Institut Francais De Damas, Damaskus. 
Tottoli, Roberto, 2002: Biblical Prophets in the Qur'an and Muslim Literature, Curzon, Richmond.

Versteegh, C. H. M., 1993: Arabic Grammar and Qur'anic Exegesis in Early Islam. Brill, Leiden.

Wadud, Amina, 1999: Qur'ân and woman: rereading the sacred text from a woman's perspective, Oxford University Press.

Waldman, Marilyn R., 1986: "New Approaches to 'Biblical' Materials in the Qur'ân", in: W.M. Brinner \& S.D. Ricks (ed.): Studies in Islamic and Judaic Traditions, Scholars Press, Atlanta.

Wansbrough, John E., 2004 (org. 1977): Quranic Studies. Sources and Methods of Scriptural Interpretation. Prometheus Books, Amherst.

- 1978: The Sectarian Milieu : Content and Composition of Islamic Salvation History. Oxford: Oxford University Press.

Watt, W. Montgomery, 1966: Muhammad at Medina, Clarendon Press, Oxford.

, 1953: Muhammad at Mecca, Clarendon Press, Oxford.

Welch, Alford T., 1983: "Muhammad's Understanding of Himself: The Koranic Data", in: Richard G. Hovannisian \& Speros Vryonis (eds.): Islam's Understanding of Itself, Undena Publishers, Malibu. , 1960: "Al-Kur'ân", in: H.A.R. Gibb \& J.H. Kramers (eds.): Encyclopaedia of Islam, Brill, Leiden.

Wild, Stefan (red.), 1996 The Qur'an as Text, Brill, Leiden.

_ 2003: "The Self-Referentiality of the Qur'ân. Sura 3:7 as an Exegetical

Challenge," in: J.D. McAuliffe et al. (eds.): With Reverence for the Word. Medieval

Scriptural Exegesis in Judaism, Christianity, and Islam, Oxford University Press, Oxford.

Zammit, Martin R., 2002: A Comparative Lexical Study of Qur'anic Arabic, Brill, Leiden.

Zirker, Hans, 1999: Der Koran. Zugänge Und Lesarten, Primus, Darmstadt.

Zwettler, Michael, 1978: The Oral Tradition of Classical Arabic Poetry. Its Character and Implications, Ohio State University Press.

Thomas Hoffmann er ph.d., post doc. ved Institut for Tværkulturelle og Regionale Studier, Københavns Universitet. 